\title{
Staff Performance Appraisal System and its Relation to Their Job satisfaction and Empowerment: Developing Performance Appraisal Tool
}

\author{
Amal Refaat Youssif ${ }^{(1)}$, Nermin Mohamed Eid ${ }^{(2)}$,and \\ Sanaa Moustafa Safan ${ }^{(3)}$ \\ M.Sc. In Nursing, Professor, Prof, and Assist Prof, Nursing Administration, Faculty of Nursing, Menoufia \\ University
}

\begin{abstract}
Performance appraisal system (PAS) plays a vital role in overall success of an organization. An appropriate appraisal system could possibly increase nurses' job satisfaction and empowerment to provide better services to the clients. The aim of this study was to assess staff performance appraisal system and its relation to their job satisfaction and empowerment at selected hospitals at Menoufiya Governorate and develop performance appraisal tool for nurses.Design: Analytical research design. Setting: Selected hospitals at Menoufyia Governorate, Egypt, namely; Menoufiya University Hospitals, Shebin El kom Teaching Hospital, and El-Helal Hospital. Subjects: Systemic random sample was used to select 400 staff nurses, convenience sampling technique was used to select 100 head nurses \& The Snowball sampling technique was employed to select the panel subjects for Delphi Technique. Tools: a) Staff Nurse's Questionnaire (consisted of PA Questionnaire, Job Satisfaction Questionnaire, and Nurses' Empowerment Questionnaire. b) Head nurses' Questionnaire. c) Delphi technique to develop staff nurses' PA tool form. Results: The majority of the study subjects were dissatisfied with the performance appraisal form currently used. Job satisfaction of staff nurses was low. There was a significant relationship between nurses' satisfaction and the system of PA at the studied hospitals. Staff nurses were moderately empowered. Furthermore, There was a significant relationship between staff nurses' empowerment and the system of performance appraisal at the studied hospitals. Conclusion: performance appraisal system is not implemented effectively at the selected Menoufyia Governorate Hospitals thus affecting job satisfaction and empowerment of staff nurses. Recommendations: It is recommended that a structured system of performance appraisal must be used. The result of appraising performance should leave the appraiser and appraisee clear about the aims, plans and future development objectives, with specific dates for reviews set and adhered to.
\end{abstract}

Keywords: Performance appraisal, job satisfaction, nurses' empowerment, performance appraisal tool

\section{Introduction}

Performance appraisal (PA) is among the most important human resource (HR) practices. PA has increasingly become part of effective strategic approach to integrate human resource activities with business policies. It may now be seen as a generic term covering a variety of activities through which organizations seek to assess employees and develop their competencies, enhance performance and distribute rewards (1). Performance appraisal is a structured formal interaction between a subordinate and superior, that usually takes the form of a periodic interview (annual or semi-annual). The performance of the subordinates is examined and discussed with a view to identify weaknesses and strengths as well as opportunities for improvement and skills development (2).

Most modern organizations apply specific forms of performance appraisal aiming at providing employees with feedback about their performance in the appraisal period. On the other hand, it's used to facilitate the task of the organization's top management in making decisions relating to promotion or demotion. Performance appraisal is essential and useful for both the employees and the organizations. On the employees' level, it helps developing the skills and improving the capacities of employees. On the organizational level, it helps improving organizational planning and achieving the main goals of the organization efficiently and effectively (3). Many appraisal tools have been developed. Certain types of tools or review techniques include: rating scale, essay, checklist, anecdotal record, and the critical incident technique. An evaluation tool must be simple, valid, reliable, stable, objective, and able to discriminate excellent from poor performance (4). Usually organizations determine the method by which the employees' performance will be measured, although there are four general measures of output, quality, quantity, cost, and timeliness. Ideally, rating supervisors should be completely objective in their appraisals of employees. Each appraisal should directly reflect an employee's performance, not any biases of a supervisor. Of course, this is impossible to do perfectly as most raters either 
intentionally or unintentionally commit errors. Raters need to be aware of these biases, so that their effect on the appraisals can be limited or eliminated (5).

Employee job satisfaction is the fulfillment, gratification, and enjoyment that come from work. It is not just the money or the fringe benefits, but the feelings employees receive from the work itself. It is a pleasurable or positive emotional state resulting from the appraisal of one's job or job experiences. In another way, it is defined simply as how people feel about their jobs and different aspects of their jobs (6). Factors influencing job satisfaction were classified into three groups; organizational policies and procedures, working condition and personal characteristics. Organizational policies and procedures are concerned with reward system, supervision and decision making. Working conditions deal with specific aspects of job such as work load, skill variety, autonomy and the physical nature of the work environment. Personal characteristics are concerned with such things as ability to tolerate stress. If people compare their achievement and the resulting awards with the others' achievement and rewards, the result is balanced then we can talk about job satisfaction. In contrast, if the result imbalanced, then dissatisfaction will exist (7).

If management allows staff the support, the encouragement and the organizational climate, nurses can be empowered at all levels of the organization. Empowerment results in employees having a strong sense of self that encourages them to be motivated to excel (8). Empowerment must involve management practices that adopt an open communication and sharing of knowledge, power and rewards throughout the organization. Empowerment has a broad context and it can be viewed through various dimensions and perspectives (9). It can be viewed as a set of managerial practices aimed at increasing an employee's autonomy and responsibilities. These practices enable employees to discharge their job or tasks more effectively and efficiently (10).

\section{Significance of the study:-}

Research has failed to demonstrate the usefulness of performance appraisal as a managerial decisionmaking tool, and how it influences improved staff performance. In relation to the PA of nurses, very little work has been published globally. (11). Furthermore, a review of the literature revealed very few other studies dealing with the relationship between performance appraisal and empowerment of nurses. This study contributed to this gap. The investigator conducted a preliminary study to assess the current performance appraisal system at the selected study setting which revealed that nurse managers were not satisfied with the tool of performance appraisal that is currently used and nurses were not aware of the tool used for appraising their performance. Furthermore, they were not informed about the results of their appraisal. The investigator conducted this study to assess performance appraisal system of nurses and its relation to their job satisfaction and empowerment at selected hospitals at Menofiya Governorate as well as developing performance appraisal tool for staff nurses.

\section{Aim of the study:}

The aim of this study was to assess staff nurses' performance appraisal system and its relation to their job satisfaction and empowerment at selected hospitals at Menofiya Governorate and develop performance appraisal tool for staff nurses.

\section{Research hypotheses:}

1. Performance appraisal is not done effectively at Menofiya Governorate hospitals.

2. There is a significant relationship between nurses' satisfaction and the system of performance appraisal.

3. There is a significant relationship between nurses' empowerment and the system of performance appraisal.

\section{Material and Methods}

Design : The study adopted analytical research design

Setting : The This study was conducted at selected hospitals at Menoufia Governorate, Egypt, namely; Menofiya University Hospitals, Shebin El kom Teaching Hospital, and El-Helal Health Insurance Hospital.

Subjects: The subjects included in the study composed of three groups:

Group 1: Staff nurses, systemic random sample of 400 staff nurses (200 staff nurses from Menoufia University Hospitals, 128 from Shebin Elkom Teaching Hosital, and 72 nurses from El-Helal Health Insurance Hospita) .

Group2: Head nurses; non-probability convenience sampling technique was used to select 100 head nurses from the pre-mentioned hospitals.

Group3: Experts in Nursing Administration: The Snowball sampling technique was employed to select the panel subjects for Delphi Technique. The panelists' expertise is what counts when developing a panel (12). This technique resulted in panel of ten academic staff from different nursing faculties across Egypt and five nursing directors from the study settings and directors of nursing administration from the Directorate of Health Affairs Tools:

1. Staff Nurse's Questionnaire: This questionnaire consisted of two parts: 
Part I: Consisted of seven items related to demographic characteristics of the study subjects (such as age, gender, hospital name, work unit, experience, job title, and qualification).

Part II: included three major segments:

The first segment: Performance Appraisal Questionnaire: Developed by Abu-Musa (13), and modified by the investigator based on the current related literature. This tool aimed to assess nurses' opinion about actual performance appraisal system at their hospitals.

Scoring system of Performance Appraisal Questionnaire:The subjects response was rated on a three point Likert scale (1disagree, 2 uncertain and 3 for agree). Therefore the maximum possible score was one hundred and fourteen. If nurses agreed on $70 \%$ or more of items of performance appraisal questionnaire, performance appraisal system was considered as effective system.

The second segment: Job Satisfaction Questionnaire developed by the investigator based on the current related literature . This questionnaire aimed to assess nurses' satisfaction with their performance appraisal system. It consisted of 13 items.

Scoring system of job satisfaction questionnaire: The scoring system of this tool ranged from (1-3). Unsatisfied response was assigned a score of "one", uncertain response was assigned a score of "two", and satisfied response was assigned a score of "three". Therefore the maximum possible score was thirty nine $(100 \%)$. If the nurse was satisfied with $60 \%$ or more of items of the job satisfaction questionnaire, the nurse was considered satisfied with the hospital performance appraisal system.

The third segment: Nurses' Empowerment Questionnaire: This segment consisted of two scales; The Conditions of Work Effectiveness Questionnaire (CWEQ-II). The CWEQ-II was used to measure staff nurses' perceptions of their access to four work empowerment structures. Items of the questionnaire were derived from Kanter's(14) original ethnographic study of work empowerment and modified by Chandler (15) for use in a nursing population then modified by the investigator. The second scale; Psychological Empowerment Scale constructed by Spreitzer (16). It was used to measure psychological empowerment. It is a self report questionnaire designed to measure the four dimensions of psychological empowerment conceptualized by Thomas and Velthouse (17): Meaning, competence, self determination and impact. This instrument consists of 9 items. One global item was added to the questionnaire as a validation index.

Scoring system of Nurses' Empowerment Questionnaire

Conditions of Work Effectiveness Questionnaire\& Psychological Empowerment: The possible responses range from 1 to 3 on the subscales: 1 (none), 2 (some) and 3 (a lot). An overall empowerment score of $\leq 34 \%$ was considered as poor empowerment, score of 35\%-68\% as moderate empowerment and score of $>68 \%$ as good empowerment .

2. Head nurses' Questionnaire: This questionnaire consists of two parts:

Part I: Consisted of seven items related to demographic characteristics of head nurses (personal and professional characteristics such as age, hospital name, work unit, years of experience and qualification.

Part II: Performance Appraisal Questionnaire: This part aimed to assess head nurses' experience of performance appraisal system at their hospitals. It is similar to performance appraisal questionnaire of nurses plus an extra dimension which is the performance appraisal accuracy including 3 items. This tool consisted of (42) items divided into five dimensions.

\section{Scoring system of head nurses questionnaire:}

The subjects response was rated on a three point Likert scale a score of "1", uncertain item was assigned a score of "two ", and agree item was assigned a score of "three". Therefore the maximum possible score was one hundred and twenty six. If head nurses agreed on $70 \%$ or more of items of performance appraisal questionnaire, performance appraisal system was regarded as effective system.

Tool 3.Delphi technique was used to develop staff nurses' performance appraisal tool form.

The Delphi technique, mainly developed by Dalkey \& Helmer (18) at the Rand Corporation in the 1950s, is a widely used and accepted method for achieving convergence of opinion concerning real-world knowledge solicited from experts within certain topic areas.

Content validity and reliability: A bilingual group of five experts was selected to test the content and face validity of the tool. Necessary modifications and deleting of some questions were done to reach the final valid version of the tool. The tool was considered valid from the experts' perspective. Also the tool was tested to reliability by the internal consistency coefficient alpha that was $(0.95)$.

Pilot study:

A pilot study was conducted after the development of the tool and before starting the actual data collection. The questionnaire was done on $10 \%$ of the sample who were not included in the main study sample. The time required for each student to fill the questionnaire was estimated to be 10-15 minutes. Modification of some questions was done based on the results of the pilot study. 


\section{Administrative and ethical considerations:}

Written approval was obtained from the Dean of the Nursing College, Menoufia University to collect data from the study settings. Another written approval to conduct the study at the study setting was obtained from the Medical and Nursing Directors of Menofiya University Hospitals, Shebin Elkom Teaching Hosital, and El-Helal Health Insurance Hospital. The study was conducted with careful attention to ethical standards of research and rights of the participants:

\section{Statistical design}

The data collected was tabulated and analyzed by SPSS version 21 on IBM compatible computer. Quantitative data were expressed as mean and standard deviation and analyzed by applying student t-test for comparison of two groups of normally distributed variables. One way ANOVA was used to determine whether there are any significant differences between the means of two or more independent (unrelated) groups. Qualitative data were expressed as number and percentage. The chi-square test $\left(\mathbf{X}^{2}\right)$ was used to examine differences with categorical variables. Regression analysis was used to detect association between quantitative variables (such as liner regression between PA and job satisfaction).

\section{Result}

Table (1) Presents demographic characteristics of the studied subjects. As presented in this table, the highest percentage of studied subjects $(50 \%)$ was working at University hospital. Furthermore, the majority of them $(80 \%)$ were nurses and were from Critical care unit $(57.8 \%)$. Concerning age, the majority of the studied subjects $(59.4 \%)$ were from 30 to less than 40 years. The majority of subjects $(93.6 \%)$ were females and had more than ten years of experience $(52.2 \%)$. Regarding qualifications, the highest percentage of the studied subjects $(42.2 \%)$ had bachelor degree in nursing. The majority of subjects $(70.6 \%)$ agreed that performance appraisal is conducted every year.

Table (2). Illustrates agreement on actual performance appraisal system as reported by study subjects. As shown in the table, total mean head nurses' agreement on performance appraisal system and its dimensions was considerably high while staff nurses' agreement was low. Also, there was a highly statistically significant difference between staff nurses and head nurses regarding total agreement on performance appraisal system and on all dimensions $(\mathrm{P}<0.001)$.

Figure (1) As shown in this figure, the percentage of staff nurses' job satisfaction was low at the three hospitals $(35.5 \%, 43.4 \%$, and $39.5 \%$ respectively). It is noticed from the figure that the percentage of staff nurses' job satisfaction was the highest at Shebin El Kom teaching hospital.

Figure (2) As shown in this figure, the majority of staff nurses reported a moderate level of empowerment in the three hospitals $(\geq 35 \%)$. The level of empowerment was the highest at Shebin El Kom teaching hospital then at El Helal Hospital (46.2\%, and $44.3 \%$ respectively).

Table ( 3) Shows regression analysis between performance appraisal system, job satisfaction and empowerment. As revealed from the table, there was good regression between performance appraisal system and job satisfaction $(\mathrm{P}<0.001)$. The value of $\mathrm{R}$ square $(0.581)$ represent that performance appraisal system was responsible for 58.1 percent change in job satisfaction. This table led the researcher to accept the hypothesis two. Furthermore, there was good regression between performance appraisal system and empowerment $(\mathrm{P}<$ $0.001)$. The value of $\mathrm{R}$ square (0.733) represent that performance appraisal system was responsible for 73.3 percent change in empowerment. The results of regression analysis confirmed the existence of a positive and significant relationship among performance appraisal (independent variable) and job satisfaction and empowerment (dependent variables). This table led the researcher to accept the hypothesis three.

Figure (3) As shown in this figure, there was good regression between performance appraisal system and empowerment. This means that there was a significant relationship between the system of performance appraisal and staff nurses' empowerment.

Table (4) in the final performance appraise checklist tool (Third round). As presented in the table, all dimensions and items took a percentage for inclusion more than $60 \%$ and this was the predetermined level of inclusion in the final draft of the staff nurses' performance appraisal tool checklist developed by the investigator.

\section{Discussion}

The most winning organizations in the 21 st century will be those to focus on integrated human resource (HR)processes and systems. So the role of human resource becomes more and more vital which includes personnel related areas such as, resource planning, performance appraisal system, compensations and employee relations (20).Performance appraisal is among the most critical human resource functions that brings global success for one organization. It is also important to mention that extensive frustration and dissatisfaction with performance appraisal have challenged practitioners and researchers to appraise the efficiency of performance appraisal quality (21). 
Therefore, the aim of the present study was to assess performance appraisal system for nurses and its relation to job satisfaction and empowerment of nurses at selected hospitals at Menoufiya Governorate and developing performance appraisal tool for nurses. Four hypotheses were tested in the present study. The first hypothesis was that performance appraisal is not done effectively at Menoufiya Governorate hospitals. The second hypothesis was that there is a significant relationship between nurses' satisfaction and the system of performance appraisal. The third hypothesis was that there is a significant relationship between nurses' empowerment and the system of performance appraisal. The last one was that the level of agreement on the performance appraisal tool that will be developed by the researcher will be high.

Before discussing the results related to testing the study hypotheses, light should be directed to socio demographic characteristics of the study subjects which were illustrated in table (1). Whereas the study was conducted at three hospitals; Menoufiya University Hospitals, Shebin Elkom Teaching Hospital, and El-Helal Health Insurance Hospital, the highest percentage of subjects were working at University hospital. The majority of the studied subjects were females and had from 30 to less than 40 years. Concerning years of experience, the majority of subjects had more than ten years of experience. These results are not in the same line with results of (22) who has mentioned that the majority of nurses in her study had from 1 to 5 years of experience. Regarding qualifications, the majority of subjects had bachelor degree in nursing. From the researcher point of view, this may be due to taking most of the study subjects from critical care units. This result agree with those of (23)who reported that the majority of nurses at critical care units at Menoufyia University Hospitals had bachelor degree in nursing

The first hypothesis was that performance appraisal was not done effectively at Menoufiya Governorate Hospitals. This hypothesis was true according to the present study results which was answered in the table -2 , The present study results revealed that performance appraisal was done as a routine, it is done for formality purposes as there was no feedback and because nothing was gained from it. While, total mean of the head nurses' agreement on performance appraisal system and its dimensions was high, nurses' mean total agreement was low. From the researcher point of view, this may be due to that head nurses are the direct nurses' supervisor who conduct the appraisal and believe that their process of conducting appraisal is always right. The true mirror here for evaluating the effectiveness of performance appraisal is staff nurses who undergo the appraisal. Another rational may be that the staff nurses' sample size (400) is larger than head nurses' sample size (100) in the present study, thus staff nurses' results are more generalized.

This results go in line with those of a study conducted by (24) about problems of clinical nurse performance appraisal system as participants in the study reported that the long interval between the evaluations and the impact of time on the rater judgment regarding the employee performance were factors emphasized by nurses as root causes of their PAS problems. Nurses said that the appraisal forms are yearly based, normally no evaluation is done during the year and usually the supervisor includes his impressions of the personnel during the last few weeks before the end of the year in his evaluation. These results were congruent with (25)results who suggested that in healthcare, appraisal systems are inadequately implemented, with only six out of ten national health services in England ever receiving an appraisal or personal development review. However, government guidelines in England advocate that all nurses have the right to management support in care delivery. This guidance suggests that regular staff appraisal can benefit both nurses and managers.Overall, evidence suggests appraisal systems are poorly implemented, and there is a lack of knowledge and experience around them.

Also, in the same line, (26) stated that most employees perceive performance appraisal only as a routine yearly exercise to assess their performance against which they will be rewarded or penalized. Also, appraisals should not be a one-off event and they should be part of an ongoing cycle of performance management in order to change the perception of employees. All workers expect to be rewarded and recognized for their efforts. On the other hand, the present study results were not similar to those of (27) who conducted a survey about performance appraisal system (PAS) used by the financial sector in Jordan based on employees' perceptions study results and noted that the effectiveness of the PAS is highly effective.

Additionally, The present study has revealed that the study subjects were very satisfied with their performance appraisal system which was answered in the figure -1.From the researcher point of view in because it was simple and easy to complete by their superiors and the dimensions of the performance appraisal system on which employees' performance were appraised included the most relevant dimensions of the person's job. This result is supported by the findings of a study conducted by (28)in Kuwait to assess nurse job satisfaction which showed that there was a significant relationship of job satisfaction with the level of education and qualification. A higher level of qualification showed an invasive relationship with job satisfaction. Other nurse researchers indicated that nurses with less work experience, lower professional titles, and lower working positions experienced lower levels of emotional exhaustion which is positively related to job satisfaction(29). As regard to the second hypothesis of the present study, the researcher hypnotized thatthere was a significant relationship between nurses' job satisfaction and the system of performance appraisal. This hypothesis was true 
according to the present study result which was illustrated in table 3. In accordance with this result, the result of a study conducted by (30) who surveyed 6,957 employees of a large Australian public sector organization regarding their opinions and perceptions of the performance appraisal quality. The findings of this study revealed that there was a direct relationship between performance appraisal satisfaction and employee outcomes, which is mostly job satisfaction among employees. They find that employees who report a low PA quality (lowest levels of trust in supervisor, poor communication, lack of clarity about expectations, perception of a less fair PA process) also report lower levels of job satisfaction.

Concerning staff nurses' empowerment at different hospitals, the present study revealed that the majority of staff nurses reported a moderate level of empowerment in the three hospitals $(\geq 35 \%)$. And Shebin El-Kom teaching hospital had higher level of staff nurses' empowerment than University hospital and El Helal Hospital which was answered in the Figure -2. From the researcher point of view . This was not expected because the nurses at Shebin El-Kom teaching hospital have lower salaries and incentives than those at University hospital. However this result may be attributed to the fact that nurses at Shebin El-Kom teaching hospital had higher mean scores regarding years of experience, which increases their skills and abilities at work, gives them self-confidence and the ability to participate in decision-making regarding their work performance. Also diploma school staff nurses at University of Menoufiya hospitals feel threatened that they will be replaced with bachelor degree staff nurses

Along the same lines, a study conducted by (8) about relationship between organizational climate and empowerment of nurses in Menoufiya Hospitals, the same setting of the present study, supports the present study results and showed that there were a statistical significant difference between University hospital and Shebin El KomTeaching Hospital regardingstaff nurse's levels of empowerment. While the majority of staff nurses reported a moderate empowerment in both hospitals, 35.4\% of nurses at Shebin El-Kom compared with $14.0 \%$ at University hospital reported good empowerment. Shebin El-Kom teaching hospital had a higher mean score for level of empowerment

Concerning the third hypothesis, the present study revealed that there was a significant relationship between nurses' empowerment and the system of performance appraisal. This led the researcher to accept the hypothesis three which is answered in table 3and figure 3.A review of the literature revealed very few other studies dealing with the relationship between performance appraisal and empowerment. This study contributes to this gap by exploring relationship between nurses' empowerment and the system of performance appraisal. In accordance with the present study findings, the findings of a study conducted by (31) suggested that recognition and rewards for effort are key elements for the nurse to be respected within the workplace and these elements can play an important role in reducing the nursing shortage by increasing the nurse retention rates and attracting new nurses. Nurses who feel their efforts are recognized and rewarded are more likely to feel respected in their workplace and therefore feel more empowered.

In agreement with these results, a study conducted by (32) stated that the majority of the studied subjects suggested improvement of the performance appraisal form used for evaluating their performance. Most of the respondents agreed that employee participation should be enhanced during designing of performance appraisal rating format and measurement scales. They would prefer performance to be evaluated by an instrument developed by employees for reliable, valid, fair and useful performance standards and that participation of employees in the development of performance standard leads to a better performance appraisal system. Also, the results are congruent with those of a study conducted by (24) who stated that the participants acknowledged that the appraisal tools are not suitable for performance evaluation, so it cannot be rated and differentiated between nurses in various levels accurately.

A useful method for gaining consensus towards an appraisal format construction is the Delphi technique which is a way of obtaining group input for ideas and problem solving (33). The final draft of the newly developed PA tool resulted into the agreed upon performance dimensions which included namely; Attendance and punctuality, appearance, work habits, staff relations and communication, communication with patients, nursing care plan activities, safety measures, innovation, documentation, coordination, and keeping upto-date technically. The agreed upon dimensions of the newly developed staff nurses' PA tool are similar to those in the tool developed by (12) at some dimensions and different in others. This tool resulted into the agreed upon performance dimensions which included namely; quality standards, work habits, supervision/leadership, staff relations and interpersonal skills, attendance and punctuality, problem solving, oral communication, productivity results, coordination, innovation, record keeping.

\section{Conclusion}

In the light of the present study results, it can be concluded that performance appraisal system is not implemented effectively at the selected Menoufyia Governorate Hospitals and so affecting job satisfaction and empowerment of staff nurses. Staff nurses' job satisfaction was low and their level of empowerment was moderate. There was a significant relationship between ineffective implementation of performance appraisal at 
the studied hospitals and nurses' satisfaction. Also, there was a significant relationship between ineffective implementation of performance appraisal at the studied hospitals and nurses' empowerment. The majority of the study subjects were dissatisfied with the performance appraisal tool currently used and thus the investigator developed the performance appraisal checklist tool.

\section{Recommendation}

It is recommended that a structured system of performance appraisal must be used. There should be a unified system for performance appraisal adopted at all health care settings. Performance appraisal should be conducted regularly and at least every three months to provide an opportunity for continuous improvement of staff nurses' performance. The outcome of appraising staff nurses' performance should be utilized to develop the aims, plans and future development objectives and there should be specific dates (set and adhered to) for reviewing progress. Also, there should be a unified well structured tool for appraising staff nurses' performance. The investigator recommends the new tool developed by her based on experts opinions to appraise staff nurses performance.

Table 1: Demographic Characteristics of the Study Subjects $(\mathrm{N}=500)$.

\begin{tabular}{|c|c|c|}
\hline Demographic items & No & $\%$ \\
\hline $\begin{array}{l}\text { Hospital name } \\
\text { University hospital } \\
\text { Shebin El Kom teaching hospital } \\
\text { El Helal hospital } \\
\end{array}$ & $\begin{array}{l}250 \\
158 \\
92 \\
\end{array}$ & $\begin{array}{l}50.0 \\
31.6 \\
18.4\end{array}$ \\
\hline $\begin{array}{ll}\text { Unit } & \\
& \text { Critical care unit } \\
& \text { Inpatient unit } \\
& \text { Outpatient }\end{array}$ & $\begin{array}{l}289 \\
197 \\
14\end{array}$ & $\begin{array}{l}57.8 \\
39.4 \\
2.8\end{array}$ \\
\hline $\begin{array}{c}\text { Occupation: } \\
\text { Staff nurse } \\
\text { Head nurse } \\
\end{array}$ & $\begin{array}{l}400 \\
100 \\
\end{array}$ & $\begin{array}{l}80.0 \\
20.0 \\
\end{array}$ \\
\hline $\begin{array}{ll}\text { Age } & \\
& \text { Less than } 30 \\
& \text { From } 30 \text { to less than } 40 \\
& 40 \text { or more } \\
\end{array}$ & $\begin{array}{l}124 \\
297 \\
79\end{array}$ & $\begin{array}{l}24.8 \\
59.4 \\
15.8\end{array}$ \\
\hline $\begin{array}{ll}\text { Gender: } & \\
& \text { Male } \\
& \text { Female } \\
\end{array}$ & $\begin{array}{l}31 \\
469\end{array}$ & $\begin{array}{l}6.2 \\
93.6\end{array}$ \\
\hline $\begin{array}{l}\text { Qualification: } \\
\text { Diploma in nursing } \\
\text { Associate degree in nursing } \\
\text { Bachelor degree in nursing }\end{array}$ & $\begin{array}{l}198 \\
91 \\
211\end{array}$ & $\begin{array}{l}39.6 \\
18.2 \\
42.2\end{array}$ \\
\hline $\begin{array}{c}\text { Years of experience: } \\
\text { <5years } \\
5-10 \text { years } \\
>10 \text { years } \\
\end{array}$ & $\begin{array}{l}116 \\
123 \\
261\end{array}$ & $\begin{array}{l}23.4 \\
24.6 \\
52.2\end{array}$ \\
\hline $\begin{array}{l}\text { Frequency of conducting performance appraisal: } \\
\text { Every year } \\
\text { Every month }\end{array}$ & $\begin{array}{l}353 \\
167\end{array}$ & $\begin{array}{l}70.6 \\
33.4\end{array}$ \\
\hline
\end{tabular}

Table 2: Agreement on Actual Performance Appraisal Dimensions as Reported by Study Subjects (Nurses and Head nurses, No=500).

\begin{tabular}{|c|c|c|c|c|c|c|}
\hline \multirow{2}{*}{$\begin{array}{l}\text { Study Subjects } \\
\text { Performance Appraisal } \\
\text { Dimensions }\end{array}$} & \multicolumn{2}{|c|}{ Mean \pm Std. Deviation } & \multicolumn{2}{|c|}{ Maximum score } & \multirow[t]{2}{*}{$\mathbf{t}$} & \multirow[t]{2}{*}{$p$-value } \\
\hline & Nurse $(\mathrm{No}=400)$ & $\begin{array}{c}\text { Head nurse } \\
(\text { No }=100)\end{array}$ & $\begin{array}{c}\text { Nurse } \\
(\mathrm{No}=400)\end{array}$ & $\begin{array}{c}\text { Head nurse } \\
(\mathrm{No}=100)\end{array}$ & & \\
\hline Performance fairness & $14.72 \pm 2.42$ & $27.74 \pm 5.46$ & 39 & 39 & 35.75 & 0.001 \\
\hline Performance incentives & $5.42 \pm 0.84$ & $10.31 \pm 2.43$ & 15 & 15 & 33.21 & 0.001 \\
\hline Performance errors & $13.75 \pm 3.49$ & $20.84 \pm 3.44$ & 30 & 30 & 18.20 & 0.001 \\
\hline Performance factors & $14.43 \pm 3.16$ & $26.49 \pm 2.54$ & 30 & 30 & 35.38 & 0.001 \\
\hline $\begin{array}{l}\text { Total agreement on performance } \\
\text { acppraisal system }\end{array}$ & $48.32 \pm 6.17$ & $85.38 \pm 7.88$ & 114 & 126 & 50.66 & 0.001 \\
\hline
\end{tabular}

Level of significance $<0.05$ 
Figure (1) Staff Nurses' Job Satisfaction in relation to the Study Hospitals

$(\mathrm{No}=400)$

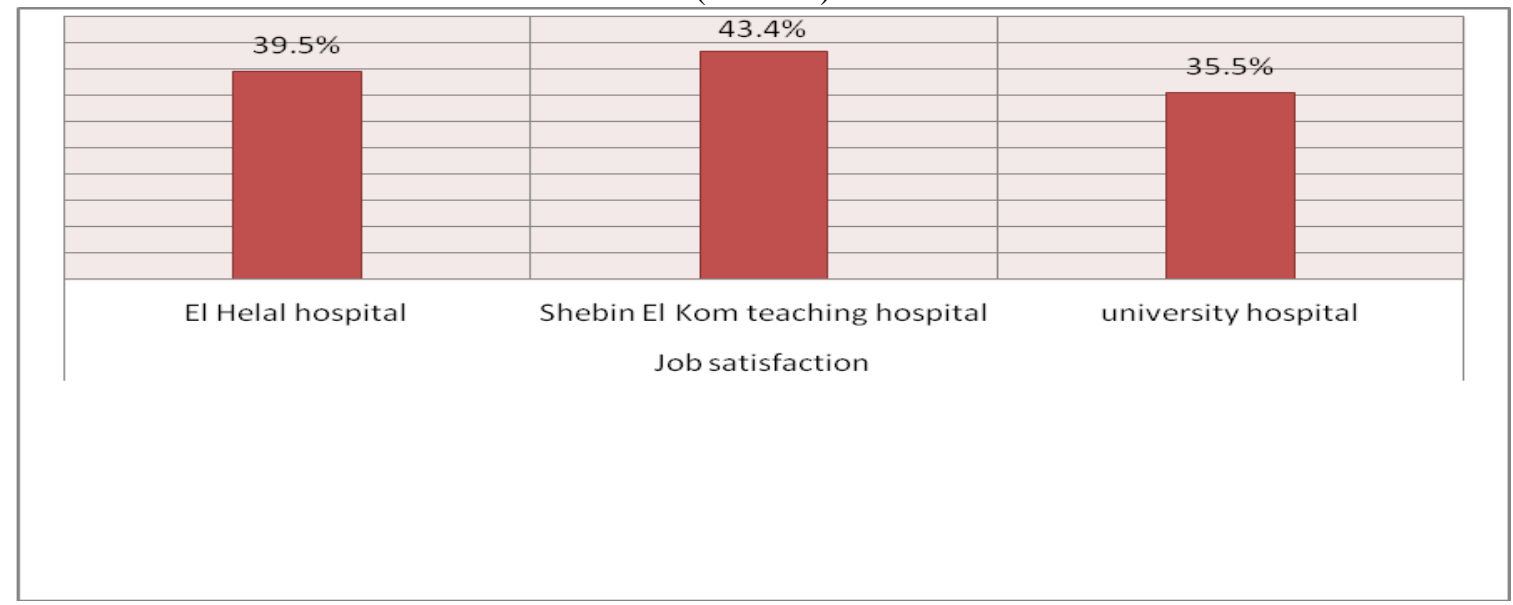

Figure (2) Empowerment of Staff Nurses in Relation to the study Hospitals $(\mathrm{No}=400)$

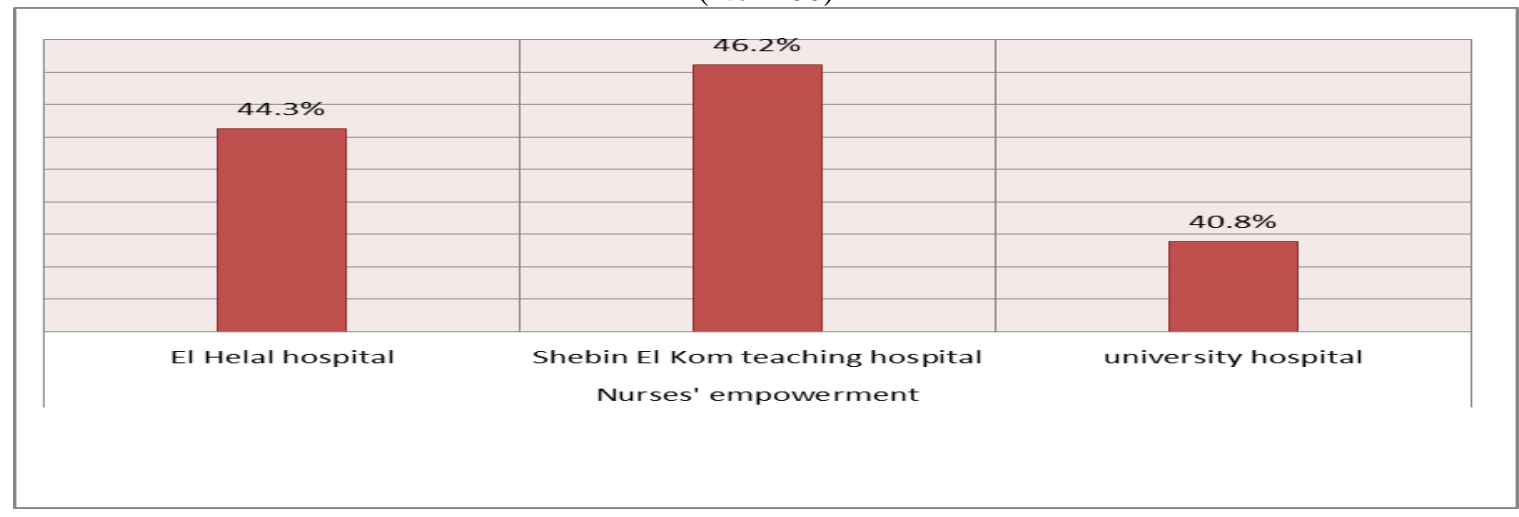

Table (3) Regression analysis between performance appraisal system, job satisfaction and empowerment

\begin{tabular}{|l|l|l|l|l|}
\hline \multirow{2}{*}{ Model } & \multicolumn{2}{|c|}{ Dependent Variable: Job satisfaction } & \multicolumn{2}{c|}{ Dependent Variable: Empowerment } \\
\cline { 2 - 5 } & \multicolumn{2}{|c|}{ R Square } & $\mathbf{P}$ - value & \multicolumn{2}{c|}{ R Square } & $\mathbf{P}-$ value \\
\hline $\begin{array}{l}\text { Performance appraisal } \\
\text { system }\end{array}$ & $\mathbf{. 5 8 1}$ & $\mathbf{0 . 0 0 0}$ & $\mathbf{. 7 3 3}$ & $\mathbf{0 . 0 0 0}$ \\
\hline
\end{tabular}

Figure (3) Regression Analysis of the Relationship between Actual Performance Appraisal System and Empowerment

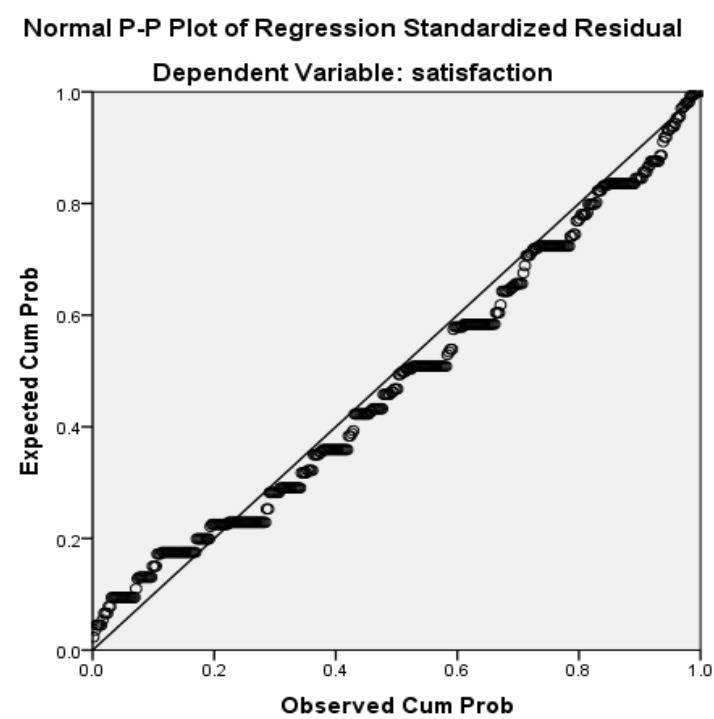


Table (4) Number and Percentage Distribution of Experts Opinions of Items to Be Included in the final Performance Appraise Checklist Tool (Third round) $(\mathrm{No}=15)$

\begin{tabular}{|c|c|c|c|c|c|c|}
\hline \multirow{2}{*}{ Items } & \multicolumn{2}{|c|}{$\begin{array}{c}\text { Yes } \\
3\end{array}$} & \multicolumn{2}{|c|}{$\begin{array}{c}\text { Cannot tell } \\
2\end{array}$} & \multicolumn{2}{|c|}{$\begin{array}{c}\text { No } \\
1\end{array}$} \\
\hline & No & $\%$ & No & $\%$ & No & $\%$ \\
\hline \multicolumn{7}{|l|}{ Item to be included in the face sheet } \\
\hline Department name & 15 & $100 \%$ & 0 & 0.00 & 0 & 0.00 \\
\hline Appraiser name & 15 & $100 \%$ & 0 & 0.00 & 0 & 0.00 \\
\hline Nurse name & 15 & $100 \%$ & 0 & 0.00 & 0 & 0.00 \\
\hline Date of appointment & 15 & $100 \%$ & 0 & 0.00 & 0 & 0.00 \\
\hline Nurse experience in the current position & 15 & $100 \%$ & 0 & 0.00 & 0 & 0.00 \\
\hline Date of appraisal & 15 & $100 \%$ & 0 & 0.00 & 0 & 0.00 \\
\hline Result of previous Appraisal & 12 & 80 & 0 & 0.00 & 3 & 20 \\
\hline Current performance Appraisal results & 15 & $100 \%$ & 0 & 0.00 & 0 & 0.00 \\
\hline Guidelines & 15 & $100 \%$ & 0 & 0.00 & 0 & 0.00 \\
\hline \multicolumn{7}{|l|}{ 冈 $\quad$ Performance appraisal dimension Inclusion } \\
\hline \multicolumn{7}{|l|}{ 1. Attendance and Punctuality } \\
\hline - $\quad$ Start work on time. & 15 & $100 \%$ & 0 & 0.00 & 0 & 0.00 \\
\hline Not exceed the identified limits of absentism. & 15 & $100 \%$ & 0 & 0.00 & 0 & 0.00 \\
\hline - $\quad$ Not leave the unit during working hours. & 13 & 86.66 & 0 & 0.00 & 2 & 13.33 \\
\hline \multicolumn{7}{|l|}{ 2. Appearance } \\
\hline - Wear complete uniform. & 15 & $100 \%$ & 0 & 0.00 & 0 & 0.00 \\
\hline Wear clean uniform. & 15 & $100 \%$ & 0 & 0.00 & 0 & 0.00 \\
\hline - Wear ironed and neat uniform & 15 & $100 \%$ & 0 & 0.00 & 0 & 0.00 \\
\hline - $\quad$ Omit jewelries in clinical area. & 15 & $100 \%$ & 0 & 0.00 & 0 & 0.00 \\
\hline \multicolumn{7}{|l|}{ 3. Work Habits } \\
\hline - $\quad$ Follow the applicable laws, rules, policies, and directives. & 13 & 86.66 & 0 & 0.00 & 2 & 13.33 \\
\hline Accept instructions related to her work. & 15 & $100 \%$ & 0 & 0.00 & 0 & 0.00 \\
\hline Have obedience and politeness attitude. & 13 & 86.66 & 1 & 6.66 & 1 & 6.66 \\
\hline Adheres to work schedules & 15 & $100 \%$ & 0 & 0.00 & 0 & 0.00 \\
\hline Complete assignments on time. & 15 & $100 \%$ & 0 & 0.00 & 0 & 0.00 \\
\hline Responds to unscheduled requests on a timely basis. & 11 & 73.4 & 1 & 6.66 & 3 & 20 \\
\hline Is available during crunch times to work extra hours. & 12 & 80 & 0 & 0.00 & 3 & 20 \\
\hline - $\quad$ Takes responsibility for his/her own work. & 15 & $100 \%$ & 0 & 0.00 & 0 & 0.00 \\
\hline $\begin{array}{l}\text { 4. Staff relations and communication } \\
\text { - } \quad \text { Communicates in a good manner with all staff. }\end{array}$ & 13 & 86.66 & 0 & 0.00 & 2 & 13.33 \\
\hline - $\quad$ Respects all members of the health care team. & 15 & $100 \%$ & 0 & 0.00 & 0 & 0.00 \\
\hline - $\quad$ Collaborates with her colleges to achieve the unit objectives. & 14 & 93.33 & 0 & 0.00 & 1 & 6.66 \\
\hline $\begin{array}{l}\text { - Follow the ethical guidelines in communicating with the health care } \\
\text { team }\end{array}$ & 14 & 93.33 & 0 & 0.00 & 1 & 6.66 \\
\hline - $\quad$ Has a positive sharing voice in matters of work unit. & 10 & 66.66 & 1 & 6.66 & 4 & 26.66 \\
\hline $\begin{array}{ll}- & \text { Providing information to superiors that is: } \\
- & \text { Complete }\end{array}$ & 14 & 93.33 & 0 & 0.00 & 1 & 6.66 \\
\hline $\begin{array}{ll}- & \text { Reliable } \\
\end{array}$ & 15 & 100 & 0 & 0.00 & 0 & 0.00 \\
\hline$-\quad$ Prompt & 13 & 86.66 & 0 & 0.00 & 2 & 13.33 \\
\hline $\begin{array}{l}\text { 5. } \text { Communication with patients } \\
\text { - } \quad \text { Respect the dignity of each patient. }\end{array}$ & 9 & 60 & 1 & 6.66 & 5 & 33.33 \\
\hline - $\quad$ Keep confidential information of patients. & 15 & 100 & 0 & 0.00 & 0 & 0.00 \\
\hline Responds to patient's needs on time. & 12 & 80 & 0 & 0.00 & 3 & 20 \\
\hline Is alert to verbal and non verbal responses. & 13 & 86.66 & 0 & 0.00 & 2 & 13.33 \\
\hline Is calm and gentle during patient care activities. & 15 & $100 \%$ & 0 & 0.00 & 0 & 0.00 \\
\hline Behave ethically and politely with patients. & 14 & 93.33 & 0 & 0.00 & 1 & 6.66 \\
\hline - $\quad$ Explain the plan of care to patients. & 15 & $100 \%$ & 0 & 0.00 & 0 & 0.00 \\
\hline $\begin{array}{l}\text { 6. } \text { Nursing care plan activities } \\
\text { - } \quad \text { Collect subjective data about the patient. }\end{array}$ & 15 & $100 \%$ & 0 & 0.00 & 0 & 0.00 \\
\hline - $\quad$ Collect objective data about the patient. & 14 & 93.33 & 1 & 6.66 & 0 & 0.00 \\
\hline Correctly define nursing diagnosis based on assessment data. & 11 & 73.33 & 3 & 20 & 1 & 6.66 \\
\hline Set priorities for patient's problems. & 15 & $100 \%$ & 0 & 0.00 & 0 & 0.00 \\
\hline Prescribe suitable intervention clearly. & 15 & $100 \%$ & 0 & 0.00 & 0 & 0.00 \\
\hline - $\quad$ Apply preventive measures to prevent hazards according to needs. & 15 & $100 \%$ & 0 & 0.00 & 0 & 0.00 \\
\hline Prepare clear discharge plan according to patient's needs. & 13 & 86.66 & 1 & 6.66 & 1 & 6.66 \\
\hline - $\quad$ Evaluate the patient's response to intervention. & 15 & $100 \%$ & 0 & 0.00 & 0 & 0.00 \\
\hline $\begin{array}{l}\text { 7. Material planning } \\
\text { - } \quad \text { Assessing needs for equipment, materials, and processing. }\end{array}$ & 10 & 66.66 & 1 & 6.66 & 4 & 26.66 \\
\hline $\begin{array}{l}\text { 8. Safety measures and patient safety } \\
\text { - Wash hands before and after any procedure. }\end{array}$ & 15 & $100 \%$ & 0 & 0.00 & 0 & 0.00 \\
\hline - $\quad$ Put needed personal protectives during patient care activities e.g. gloves, & 15 & $100 \%$ & 0 & 0.00 & 0 & 0.00 \\
\hline
\end{tabular}




\begin{tabular}{|c|c|c|c|c|c|c|}
\hline \multirow[t]{2}{*}{ Items } & \multicolumn{2}{|c|}{$\begin{array}{c}\text { Yes } \\
3\end{array}$} & \multicolumn{2}{|c|}{$\begin{array}{l}\text { Cannot tell } \\
2\end{array}$} & \multicolumn{2}{|c|}{$\begin{array}{c}\text { No } \\
1\end{array}$} \\
\hline & No & $\%$ & No & $\%$ & No & $\%$ \\
\hline masks, .....etc. & & & & & & \\
\hline $\begin{array}{l}\text { - Follow safety measures to avoid physical hazards e.g. avoid bedside } \\
\text { rails, infection control guidelines. }\end{array}$ & 15 & $100 \%$ & 0 & 0.00 & 0 & 0.00 \\
\hline $\begin{array}{l}\text { - Organizing work site in such a way that it is neat and clear of potential } \\
\text { hazards. }\end{array}$ & 15 & $100 \%$ & 0 & 0.00 & 0 & 0.00 \\
\hline Seek agreement from patient before any procedure. & 15 & $100 \%$ & 0 & 0.00 & 0 & 0.00 \\
\hline $\begin{array}{l}\text { 9. Innovation } \\
\text { - } \quad \text { Developing new solutions to work problems. }\end{array}$ & 9 & 60 & 0 & 0.00 & 6 & 40 \\
\hline $\begin{array}{l}\text { - Exhibiting creativity in the development of new or improved methods or } \\
\text { approaches. }\end{array}$ & 9 & 60 & 0 & 0.00 & 6 & 40 \\
\hline Organized. & 11 & 73.33 & 0 & 0.00 & 4 & 26.66 \\
\hline Easy-to read. & 11 & 73.33 & 0 & 0.00 & 4 & 26.66 \\
\hline Written in ink. & 12 & 80 & 0 & 0.00 & 3 & 20 \\
\hline Document everything on time. & 14 & 93.33 & 0 & 0.00 & 1 & 6.66 \\
\hline Record clearly current condition of patient. & 15 & $100 \%$ & 0 & 0.00 & 0 & 0.00 \\
\hline Record progress in patient condition. & 15 & $100 \%$ & 0 & 0.00 & 0 & 0.00 \\
\hline Record all procedures performed. & 15 & $100 \%$ & 0 & 0.00 & 0 & 0.00 \\
\hline - $\quad$ Providing others with complete and accurate written directions. & 12 & 80 & 0 & 0.00 & 3 & 20 \\
\hline $\begin{array}{l}\text { 11. Coordination } \\
\text { Utilizing available support services (e.g. laboratory, laundry, pharmacy) } \\
\text { effectively. }\end{array}$ & 10 & 66.66 & 1 & 6.66 & 4 & 26.66 \\
\hline $\begin{array}{l}\text { 12. Keeping up-to-date technically. } \\
\text { Serving as a "resource person" on whom others rely for technical advice. }\end{array}$ & 11 & 73.33 & 0 & 0.00 & 4 & 26.66 \\
\hline - $\quad$ Skillful in procedures specific to the work area. & 14 & 93.33 & 0 & 0.00 & 1 & 6.66 \\
\hline Knowledgeable about common diseases in his/her work area. & 15 & 100 & 0 & 0.00 & 0 & 0.00 \\
\hline Demonstrating effort and success at self-improvement. & 14 & 93.33 & 0 & 0.00 & 1 & 6.66 \\
\hline - $\quad$ Striving to achieve objectives beyond what is expected or required. & 11 & 73.33 & 1 & 6.66 & 3 & 20 \\
\hline Item to be included in the summary sheet & & & & & & \\
\hline - $\quad$ Summary of strengths and weakness & 15 & $100 \%$ & 0 & 0.00 & 0 & 0.00 \\
\hline Summary of areas where improvements can be made & 15 & $100 \%$ & 0 & 0.00 & 0 & 0.00 \\
\hline $\begin{array}{l}\text { - Specific actions to be taken over the next year (e.g. training programs, } \\
\text { changes in procedures, new job assignments, etc.) }\end{array}$ & 15 & $100 \%$ & 0 & 0.00 & 0 & 0.00 \\
\hline $\begin{array}{l}\text { Employee comments (this area provides a place for the employee to } \\
\text { react to the evaluation itself as well as other topics). }\end{array}$ & 15 & $100 \%$ & 0 & 0.00 & 0 & 0.00 \\
\hline $\begin{array}{l}\text { Signature and approvals (employee signature denotes that the } \\
\text { employee has read and understands the evaluation and agrees with } \\
\text { the result). } \\
\text { Signature of employee. }\end{array}$ & 15 & $100 \%$ & 0 & 0.00 & 0 & 0.00 \\
\hline Signature of rater. & 15 & $100 \%$ & 0 & 0.00 & 0 & 0.00 \\
\hline Signature of hospital director. & 15 & $100 \%$ & 0 & 0.00 & 0 & 0.00 \\
\hline
\end{tabular}

\section{Reference}

[1]. Dargham, N. (2008). Effective management of the performance appraisal process in Lebanon: an Exploratory Study. Available at: http://www.fgm.usj.edu.lb/pdf/a12008.pdf.

[2]. Singh P., \& Gupta S. (2013). Performance appraisal: Building trust among employees or not-the dilemma continues. International Journal of Scientific and Research Publications, 3(8), pp. 1,2. August 2013.

[3]. Armstrong, M. (2009). Business \& economics. "Armstrong's handbook of performance management". 4th ed. Comp. London and Philadelphia. https://books.google.com.eg/books?isbn=0749458429

[4]. Huston C. and Marquis B. (2013). Performance appraisal. Leadership Roles and Management Functions in Nursing: Theory and Application. Seventh ed. North American.. Ch. 24. Pp.524-540.

[5]. Al Kahtani A, (2013). Employee emotional intelligence and employee performance in the higher education institutions in Saudi Arabia: a proposed theoretical framework. International Journal of Business and Social Science, 4 (9); August 2013.ijbssnet.com/journals/Vol_4_No_9_August_2013/7.pdf.

[6]. Asegid A, Belachew, T., and Yimam, E. (2014). Factors influencing job satisfaction and anticipated turnover among nurses in Sidama zone public health facilities. South Ethiopia. Nursing Research and Practice. Volume 2014 (2014), pp.26.

[7]. Hyun S, (2009). Re-examination of Herzberg's two factor theory of motivation in the Korean Army food service operation. Iowa state university. Digital repository @ iowa state university.

[8]. Abd El-Salam, G., Ibrahim, M., Mohsen, M and Hassanein, S. (2008). Relationship between organizational climate and empowerment of nurses in Menoufiya Hospitals, Egypt. Eastern Mediterranean Health Journal, 14(5):1173-1183.

[9]. Ayupp K., \& Chung, H. (2010). Empowerment: Hotel employees' perspective. Faculty of Economics \& Business - University Malaysia Sarawak. Journal of Industrial Engineering and Management (JIEM), 3(3): 561-575. Available at : http://upcommons.upc.edu/bitstream/handle/2099/9951/ayupp.pdf. 
[10]. Chen, K. (2011). A study on the impact of empowerment on employee performance in the automotive industry. MS.C. Centre for graduate studies. Open University of Malaysia.

[11]. Nachamba, L. (2008). Examination of open staff performance appraisal system at selected health facilities in Malawi. MSc. Thesis. Faculty of Nursing. University of Malawi.

[12]. Zaghloul, A \& AlSokair, K. (2008). Constructing a nurse appraisal form: A Delphi technique study. Journal of Multidisciplinary Healthcare, 1 (1):1-14

[13]. Abu-Musa, J. (2008). Staff satisfaction on Performance Appraisal System and its Incentives in the Gaza Field Office. The Islamic University of Gaza graduates studies. Deanery business administration dept. College of Commerce. MS.c.

[14]. Kanter, M. (1993). Men and women in the corporation, $2^{\text {nd }}$ ed. Basic books, New York.

[15]. Chandler, G. (1986). The relationship of nursing work environment to empowerment and powerlessness. PhD. University of Utah.

[16]. Spreitzer, G. (1995). Psychological empowerment in the workplace: Dimensions, measurement, and validation. Academy of Management Journal, 38 (5): 1442-1464.

[17]. Thomas, K. \& Velthouse B. (1990). "Cognitive elements of empowerment: an "interpretive” model of intrinsic task motivation", Academy of Management Review, 15(4): 666-681.

[18]. Dalkey C., \& Helmer, O. (1963). An experimental application of the Delphi method to the use of experts. Management Science, 9(3), 458-467.

[19]. Custer, L., Scarcella, J. \& Stewart, R. (1999). The modified Delphi technique: a rotational modification. Journal of Vocational and Technical Education, 15(2), 1-10.

[20]. Dechev, Z. (2010). Effective performance appraisal - a study into the relation between employer satisfaction and optimizing business results. MS.C. Erasmus University Rotterdam. Faculty of Economics of Business.

[21]. Darehzereshki M. (2013). Effects of performance appraisal quality on job satisfaction in multinational companies in Malaysia. International Journal of Enterprise Computing and Business systems (online), 2(1), 2230-8849.

[22]. Nassar R. (2011). Effects of models of organizing patient care on productivity at Shebin El Kom Hospitals. Faculty of Nursing Menoufyia University. M.Sc. P.76.

[23]. Ageiz, M. (2012). The health care working conditions that affect patient safety as perceived by the nursing staff. Faculty of Nursing. Menoufyia University. M.Sc. p. 102-105.

[24]. Nikpeyma N, Abed Saeedi Z, Azargashb E, Majd, H. (2014). Problems of clinical nurse performance appraisal system: a qualitative study. Asian Nursing Research, 8(1), 15-22.

[25]. Duffin C. (2006). Trusts falling behind with staff appraisals, NHS survey. Nursing standard; 20: 29, 8

[26]. Tippins, T. and Coverdale, H. (2009). Performance management of the future. In Smither, J.W. \& London, M. (Eds.), Performance management; putting research into action (pp. 555-583). San Francisco; Jossey-Bass

[27]. Al-Zawahreh A., and Khasawneh, S. (2009). An analysis of the performance appraisal system in the Jordanian financial sector: an international perspective. African Journal of Business Management.

[28]. Al-Enezi N., Chowdhury R., Shah M., \& Al-Otabi M. (2009). "Job satisfaction of nurses with multicultural backgrounds: A questionnaire survey in Kuwait," Applied Nursing Research, 22( 2): 94-100.

[29]. Lin F., John W., \& McVeigh C. (2009). "Burnout among hospital nurses in China”. Journal of Nursing Management, 17 (3), pp. 294-301.

[30]. Brown, M., Haytt, D., \& Benson, J. (2010). Consequences of the performance appraisal experience. 39 (3), $375-396$

[31]. Guerrettaz, T. (2012). Workplace empowerment, incivility, and burnout: impact on staff nurses recruitment and retention outcomes. M.SC., Ball State University, Muncie, India.

[32]. Onyango, B., (2013). Factors influencing employee perception of performance appraisal at national housing corporation. M.Sc. in Business Administration. School of Business. University of Nairobi.

[33]. Pelletier D, Duffield C, \& Adams A. (1997). The cardiac nurse's role: an Australian Delphi study perspective. Clinical Nurse Specialist, 11:255-63. 